\title{
Flow or Fence: Learning, Preserving, and Redefining the Riverfront Cultural Landscape
}

\author{
Ariya Aruninta ${ }^{1}$, Hajime Matsushima ${ }^{2}$, Pachara Phukumchai ${ }^{1}$ \\ ${ }^{1}$ Department of Landscape Architecture, Chulalongkorn University, Bangkok, Thailand \\ ${ }^{2}$ Faculty of Agriculture, Hokkaido University, Sapporo, Japan \\ Email: aariya@chula.ac.th
}

How to cite this paper: Aruninta, A. Matsushima, H. and Phukumchai, P. (2020) Flow or Fence: Learning, Preserving, and Redefining the Riverfront Cultural Landscape. Journal of Water Resource and Protection, 12, 921-933.

https://doi.org/10.4236/jwarp.2020.1211054

Received: October 8, 2020

Accepted: November 22, 2020

Published: November 25, 2020

Copyright $\odot 2020$ by author(s) and Scientific Research Publishing Inc. This work is licensed under the Creative Commons Attribution International License (CC BY 4.0).

http://creativecommons.org/licenses/by/4.0/

\begin{abstract}
The Chao Phraya River and the network of canals or "klongs" are the origin of Bangkok's nick-name "Venice of the East". Its amphibian nature of lower delta area where used to be covered by the sea around 5000 years ago provides a water-based settlement for the citizens. Rivers as an agricultural irrigation system are also used for daily consumption, transportation, and drainage channels. Bangkok was established in 1782 as the capital of Thailand by King Rama I of the Chakri Dynasty. The location is on a flood plain delta of the Chao Phraya River with the same consideration as the up north old capital Ayutthaya; the river is performed as a natural defense against enemies and also provides a water-based settlement for the citizens. The worst flood in Thailand's history occurred during the 2011 monsoon season; July to November; that became the severest flood disaster hit parts of the capital city of Bangkok and resulted in a total of 815 deaths and 65 of Thailand's 77 provinces were declared flood disaster zones, and over 20,000 square kilometers (7700 square miles) of farmland was damaged. The most affected areas were the recent capital Bangkok and the old capital Ayutthaya. The major causes were not only from the natural disaster but also water management failures from the human disaster. The studies aimed to include the survey of after-flood areas, reviewing the history of the waterfront communities and their attitudes toward development and changes, then discussed threats and crisis to the cultural landscape, the cause and effects of the disaster, the theoretical framework of the best management practices and the resolutions models proposed by the involved authorities. Whilst, history also gives us a sense of identity and traditional wisdom, the paper tried to find a paradigm shift and invented best practices for future generation flood protection using "the meaning and spirit of cultural landscape" model.
\end{abstract}

\section{Keywords}

Cultural Landscape, Waterfront, Flood Protection, River Delta, Living with 
Water, Thailand, Agricultural Landscape, Old Communities, Resilience,

Transformation, Urbanization

\section{Introduction: The River Delta of Central Thailand}

The Chao Phraya River basin covers 20,125 square kilometers, its lower part is the sediment area which used to be covered by the sea around 5000 years ago. The recent Bangkok or Rattanakosin "Krungthep": the capital of Thailand lies on both banks near the mouth of the river. The city and the surrounding area have a dense network of canals. The total length of the Chao Phraya River is about 300 kilometers locating in the north of Bangkok in other eight provinces in the central part of Thailand. The origin of the Chao Phraya River consists of four large tributaries as the confluence of the Ping, Wang, Yom and Nan rivers. The confluence of the Ping and Wang, commences with Yom and Nan at Nakhon Sawan. There are two parts of the Chao Phraya River basin; the upper region comprises the mountainous area. The river flows down to central plains upstream, midstream region, and the swampy lower basin region at the mouth of the river to the Gulf of Thailand. This Lower delta area (midstream and downstream) from Ayutthaya through the river mouth is influenced by the tides and storm flow in the flood season.

The macro climate location of delta of the Chao Phraya River is in the monsoon area with heavy rain especially during a rainy season lasting from May to October at the average of $1300 \mathrm{~mm}$ rainfall annually and around up to $3 \mathrm{~m}$ difference of high and low tides daily at the Gulf of Thailand. These key factors create the seasonal characteristic of the riverscape dynamics, so-called "flood-pulse" [1]. The lower delta area has silt-deposits with blackish water estuary due to strong tidal action and becomes the most fertile areas for rice production in the upper part of freshwater zone, fruit orchard in the middle part of blackish water, and aquaculture in the lower part of saltwater zone. At the same time, the high tides provide strong tidal actions. This also causes salinity intrusions problems and high rates of sedimentation which should be appropriately alleviated [2].

From the past three decades, the country's development has been concentrated on promoting industry as a replacement of agriculture [3]. Agricultural land in the delta has been declining since the mid-1970s. This regression of the land frontier is very significant, most especially around Bangkok and the provinces included Pathum Thani and Nakhon Pathom. This reduction is due mainly to urban and industrial growth and to the transformation of agricultural land into real estate, sand pits, golf courses, Sunday gardens, roads, etc. [4].

The digging of the canals in 1800s formed a transversal line connecting the Chao Phraya River and the other rivers. The objective was to allow convenient transportation to Bangkok [5] [6] [7]. This land development allows very good conditions of drainage but not all of the year: the plots were still flooded during 
the rainy season (from July to November) [7] (ibid). In order to store the monsoon flows for release in the dry season, there are two largest and important dams constructed; the Bhumiphol and Sirikit Dams; the main purpose is to supply stored water for electricity generation, irrigation, and domestic and industrial water use. Together with a number of barrages have been constructed in the Lower Chao Phraya basin to control and divert the water in the canal systems that provide irrigation water to some one million hectares in this area.

In general, the critical water problems included floods in rainy season, droughts in dry season (summer and winter) and water pollution. According to hydrologic data, it shows that the annual average rainfall in Thailand varies between $1100 \mathrm{~mm}$ and $1600 \mathrm{~mm}$. During the six driest months of the year, from December to May, the country relies on the water available in 28 main irrigation dams. However, only 15 percent of the 200 billion $\mathrm{m}^{3}$ annual runoff remains trapped in the dams [8].

The Chao Phraya delta is one of the most important deltas in the central part of Thailand. In the past, the delta have been flooded frequently and in the modern days these floods result in extensive damage to economic and social condition, especially at the lower reach of the Chao Phraya River; Bangkok and vicinity. Forecasting of water level, the upstream boundary is the released discharge hydrograph at the tail of Chao Phraya Dam in Chainat Province and the downstream boundary, the water level fluctuation in the Gulf of Thailand depends on the astronomical factors; the highest tide on the full moon day and physiography of the region, while the meteorological factor is considered to produce only minor effects [9]. Hereto, water management and engineering solutions seem not efficient to attack the water problems.

Therefore, this collaboration research aimed to include the survey of after-flood areas, reviewing the history of the waterfront communities and conducting site surveys and interviewing the attitudes of riverfront communities toward development and changes, then discussed the threats and crisis to the cultural landscape, the cause and effects of the disaster, the theoretical framework of the best management practices and the resolutions models proposed by the involved authorities.

\section{Thai Wisdom on Living with Water}

More than 600 years ago, the lower flat land of the Chao Phraya River, was the settlement of water based community and orchard area. In early Ayutthaya period; in AD 2065; Ayutthaya has a close international relationship with China and Portugal via Siamese Gulf (the former name of the Gulf of Thailand) through Bangkok, Phra Chai Rachathirach was pleased in digging out the crosscut canal along the Chao Phraya River especially the curve part that similar to horse shoe (Oxbow lake) in order to eliminate sweeping bends to shortened the journey from nine to six kilometres and straightened the channel for easier navigation. As time passed by, these canals became the Chao Phraya River and the 
former Chao Phraya River became canals. This described the very authenticity of Thai way of life and engineering wisdom in the former time.

Waterway was the main transportation route, so along the water front especially the mouth and the canals intersection, there has been a mixed blend of culture and religion communities, including Muslims, Chinese merchants, and Thai. From Ayutthaya (1351-1767), Krungthonburi (1769-1782), to Rattanakosin "Krungthep" (1782-present), the location on a flood plain delta of the Chao Phraya River was originally selected with the same consideration of being a natural defense against enemies, while providing a water-based settlement for the citizens. Because of a dense network of canals, it became the origin of Bangkok's nickname "Venice of the East". The nickname best represents Ayutthaya and Bangkok as cities of waterway network nurturing riparian settlement and transportation. Although both capital cities have certain aquatic features comparable to the city of Venice, the term "Venice of the East", it does not contribute to the full understanding and appreciation of way of life, conception, beliefs, rituals, artistic and symbolic creations stemming from close association with water [10]. There was a quote from John Bowring, 1855 (Sir John Bowring, Queen Victoria's Governor of Hong Kong in Rama IV) that explained how the cultural landscape of Bangkok in the old day said: "The highways of Bangkok are not streets or roads ... but the river and the canals." The purposes of the canals are for daily consumption, transportation, an agricultural irrigation system and a drainage channel. Similar to other places in the world, the rivers always have certain definite environmental, social, cultural and economic values, as well. They are used by humans for a wide variety of purposes such as drinking water, irrigation, industry, power production, transportation, flood control, fishing, boating, swimming and aesthetic enjoyment [11].

This paper focuses and tries to compare the diverse aspects of the rivers, but the Chao Phraya River seemed to have an outstanding aspect in cultural landscape, the urbanization does not only impact to the water quality of the river but also to the tangible and intangible human geography related to the river.

\section{Research Design}

The study has reviewed the history and observed the transformation of the Chao Phraya River for many years, especially after the worst flood in 2011. The studies included the survey of after-flood areas, the ecological values, and attitudes of the communities towards development and changes, interviewing the water front communities and then discussed the threats and crisis to the cultural landscape, the cause and effects of the disaster, the theoretical framework of the best management practices, discussed the models and resolutions proposed by the involved authorities, and comparisons of the transformation and resilience of communities to the dynamic nature of the urbanization.

This paper divided the surveys into three major portions of the Chao Phraya River: upstream, midstream, and downstream. The study will present the results 
from field surveys that focused on the changes and transformation of the river front communities due to flood protection construction projects. The field surveys of dry season and rainy season were as in Table 1 . The main objective of this research is to find a paradigm shift and to invent best practices using "the meaning and spirit of cultural landscape" model for future flood protection.

\section{Survey Results: The Choices of Flow and Fence}

Thailand is facing many failures caused by the wrong decision makings in urban development policies. The Chao Phraya River basin covers not only the major cities like Bangkok and Ayutthaya but also other smaller provinces. After the worst flood in 2011, especially along the Chao Phraya River, there have been the mega flood protection structures installed. The constructions from fragmental

Table 1. Survey locations of the Chao Phraya River transformation after the worst flood in 2011.

\begin{tabular}{|c|c|c|}
\hline \multicolumn{3}{|c|}{ Dry Season-Mar $2016^{a}$} \\
\hline Upstream & Midstream & Downstream \\
\hline $15^{\circ} 41^{\prime} 59.9^{\prime \prime} \mathrm{N}+100^{\circ} 08^{\prime} 31.8^{\prime \prime} \mathrm{E}$ & $14^{\circ} 20^{\prime} 40.6^{\prime \prime} \mathrm{N}+100^{\circ} 34^{\prime} 42.1^{\prime \prime} \mathrm{E}$ & $13^{\circ} 39^{\prime} 49.9^{\prime \prime} \mathrm{N}+100^{\circ} 32^{\prime} 20.4^{\prime \prime} \mathrm{E}$ \\
\hline Sta2-Nan1: Paknam Po Railway Station & Sta7-Chao5: Wat Chaiwattanaram & Sta11-Chao9: Butterfly Fort, Samut Prakarn \\
\hline Sta3-Ping1: Wat Thep Samakeetham & Sta8-Chao6: Bang Baln/Embankment & Sta12-Chao10: Koh Kred, Nonthaburi \\
\hline $15^{\circ} 43^{\prime} 51.2^{\prime \prime} \mathrm{N}+100^{\circ} 07^{\prime} 22.3^{\prime \prime} \mathrm{E}$ & $14^{\circ} 25^{\prime} 29.9^{\prime \prime} \mathrm{N}+100^{\circ} 29^{\prime} 09.3^{\prime \prime} \mathrm{E}$ & $13^{\circ} 54^{\prime} 46.2^{\prime \prime} \mathrm{N}+100^{\circ} 29^{\prime} 30.1^{\prime \prime} \mathrm{E}$ \\
\hline Sta4-Chao2: Chao Phraya Dam, Chainat & Sta9-Chao7: Silpacheep Bangsai & \\
\hline $15^{\circ} 09^{\prime} 28.9^{\prime \prime} \mathrm{N}+100^{\circ} 10^{\prime} 48.0^{\prime \prime} \mathrm{E}$ & $14^{\circ} 09^{\prime} 08.2^{\prime \prime} \mathrm{N}+100^{\circ} 30^{\prime} 57.5^{\prime \prime} \mathrm{E}$ & \\
\hline \multirow{2}{*}{\multicolumn{3}{|c|}{$\begin{array}{l}\text { Sta5-Chao3: Wat Pa Kwai Beach, Singhaburi } \\
14^{\circ} 48^{\prime} 55.5^{\prime \prime} \mathrm{N}+100^{\circ} 26^{\prime} 27.1^{\prime \prime} \mathrm{E}\end{array}$}} \\
\hline & & \\
\hline \multicolumn{3}{|c|}{ Rainy Season-Sep $2017^{\mathrm{b}}$} \\
\hline Upstream & Midstream & Downstream \\
\hline Sta1-Chao1: Rim Kheun & Sta7-Chao5: Athithara Homestay, Ayutthaya & Sta12-Chao10: Pak Nam Non/Koh Kred \\
\hline $15^{\circ} 42^{\prime} 05.9^{\prime \prime} \mathrm{N}+100^{\circ} 08^{\prime} 26.9^{\prime \prime} \mathrm{E}$ & $14^{\circ} 20^{\prime} 24.0^{\prime \prime} \mathrm{N}+100^{\circ} 32^{\prime} 55.7^{\prime \prime} \mathrm{E}$ & $13^{\circ} 54^{\prime} 47.0^{\prime \prime} \mathrm{N}+100^{\circ} 29^{\prime} 30.1^{\prime \prime} \mathrm{E}$ \\
\hline Sta2-Nan1: boat cruise & Sta8-Chao6: Japanese Village & Sta13-Chao11: Bangka-chao \\
\hline $15^{\circ} 42^{\prime} 11.6^{\prime \prime} \mathrm{N}+100^{\circ} 09^{\prime} 07.4^{\prime \prime} \mathrm{E}$ & $14^{\circ} 19^{\prime} 59.2^{\prime \prime} \mathrm{N}+100^{\circ} 34^{\prime} 37.0^{\prime \prime} \mathrm{E}$ & $13^{\circ} 40^{\prime} 48.8^{\prime \prime} \mathrm{N}+100^{\circ} 35^{\prime} 08.0^{\prime \prime} \mathrm{E}$ \\
\hline Sta3-Chao2: Shrine & Sta9-Chao7: Wat Chaiwattanaram & Sta14-Chao12: Santichaiprakarn Fort Park \\
\hline $15^{\circ} 42^{\prime} 00.3^{\prime \prime} \mathrm{N}+100^{\circ} 08^{\prime} 31.5^{\prime \prime} \mathrm{E}$ & $14^{\circ} 20^{\prime} 36.8^{\prime \prime} \mathrm{N}+100^{\circ} 32^{\prime} 34.0^{\prime \prime} \mathrm{E}$ & $13^{\circ} 45^{\prime} 52.2^{\prime \prime} \mathrm{N}+100^{\circ} 29^{\prime} 43.2^{\prime \prime} \mathrm{E}$ \\
\hline $15^{\circ} 43^{\prime} 49.9^{\prime \prime} \mathrm{N}+100^{\circ} 07^{\prime} 00.4^{\prime \prime} \mathrm{E}$ & $14^{\circ} 25^{\prime} 43.5^{\prime \prime} \mathrm{N}+100^{\circ} 28^{\prime} 59.4^{\prime \prime} \mathrm{E}$ & \\
\hline Sta5-Chao3: Chainat Lakmuang & Sta11-Chao9: Bangpa-in, Wat Nivet & \\
\hline $15^{\circ} 11^{\prime} 03.1 " \mathrm{~N}+100^{\circ} 07^{\prime} 22.1^{\prime \prime} \mathrm{E}$ & $14^{\circ} 13^{\prime} 47.2^{\prime \prime} \mathrm{N}+100^{\circ} 34^{\prime} 34.2^{\prime \prime} \mathrm{E}$ & \\
\hline \multicolumn{3}{|l|}{ Sta6-Chao4: Chao Phraya Dam } \\
\hline $15^{\circ} 09^{\prime} 29.0^{\prime \prime} \mathrm{N}+100^{\circ} 10^{\prime} 48.3^{\prime \prime} \mathrm{E}$ & & \\
\hline
\end{tabular}

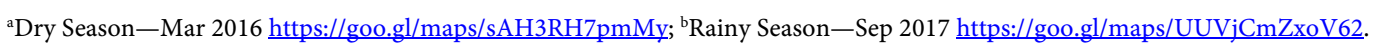


plans have been going on but the authors do not think this is the final resolution. With the dynamic nature of storm water, the climate change, and the other aspects have to be reconsidered in the decision process. The study argued that only the single engineering approach, which was focused on the earlier policies, is not the best practice. Therefore, it is a need to integrate the other approaches and utilize them in their decisions.

The survey routes started from upstream in Nakhon Sawan, followed by midstream, and end up at the mouth of the Chao Phraya at the Gulf of Thailand. The surveys in the two seasons illustrate the different nature of human geography dealing with specific part of the river; Figure 1 shows the low land and deposition of muddy sediment area, Figure 2 shows flood agricultural land, and Figure 3 shows the steeper slope embankment.

The questionnaire surveys were conducted in the waterfront communities from upstream to downstream in a total of 92 Chao Phraya riverside residents. The results showed that the residents felt the river environments getting worse, especially in downstream. They felt the amount of garbage had increased and also water quality got worse because of human activities, e.g. wastewater from households and factories, and pesticides and fertilizers in farmland.

\subsection{Mega Flood Structure and Its Impact to Communities}

Of the many changes to our world wrought during the twentieth century, one of

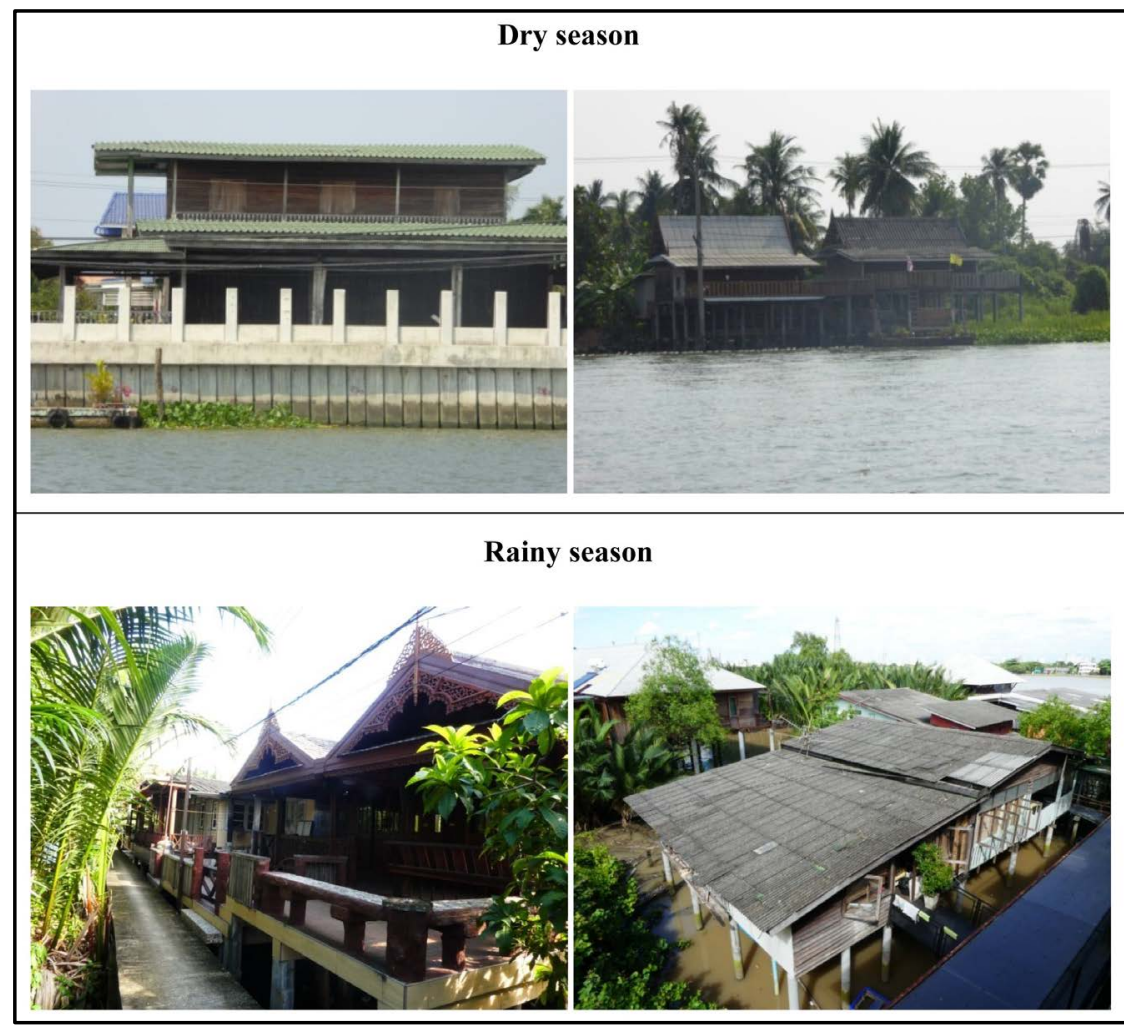

Figure 1. Survey location in downstream: low land and deposition of sediment in dry and rainy season. 


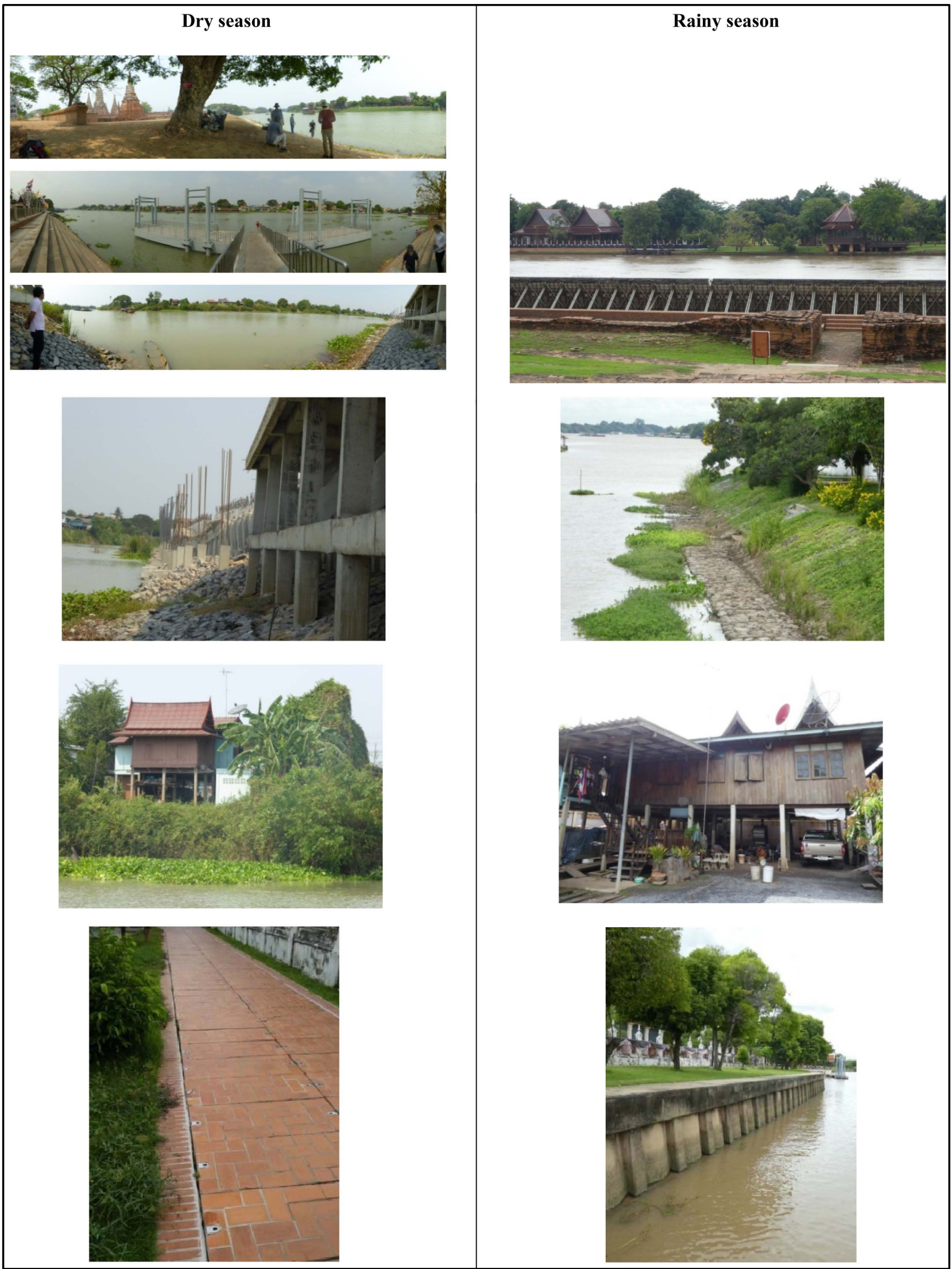

Figure 2. Survey location in midstream: flooded plains for rice field in dry and rainy season. 


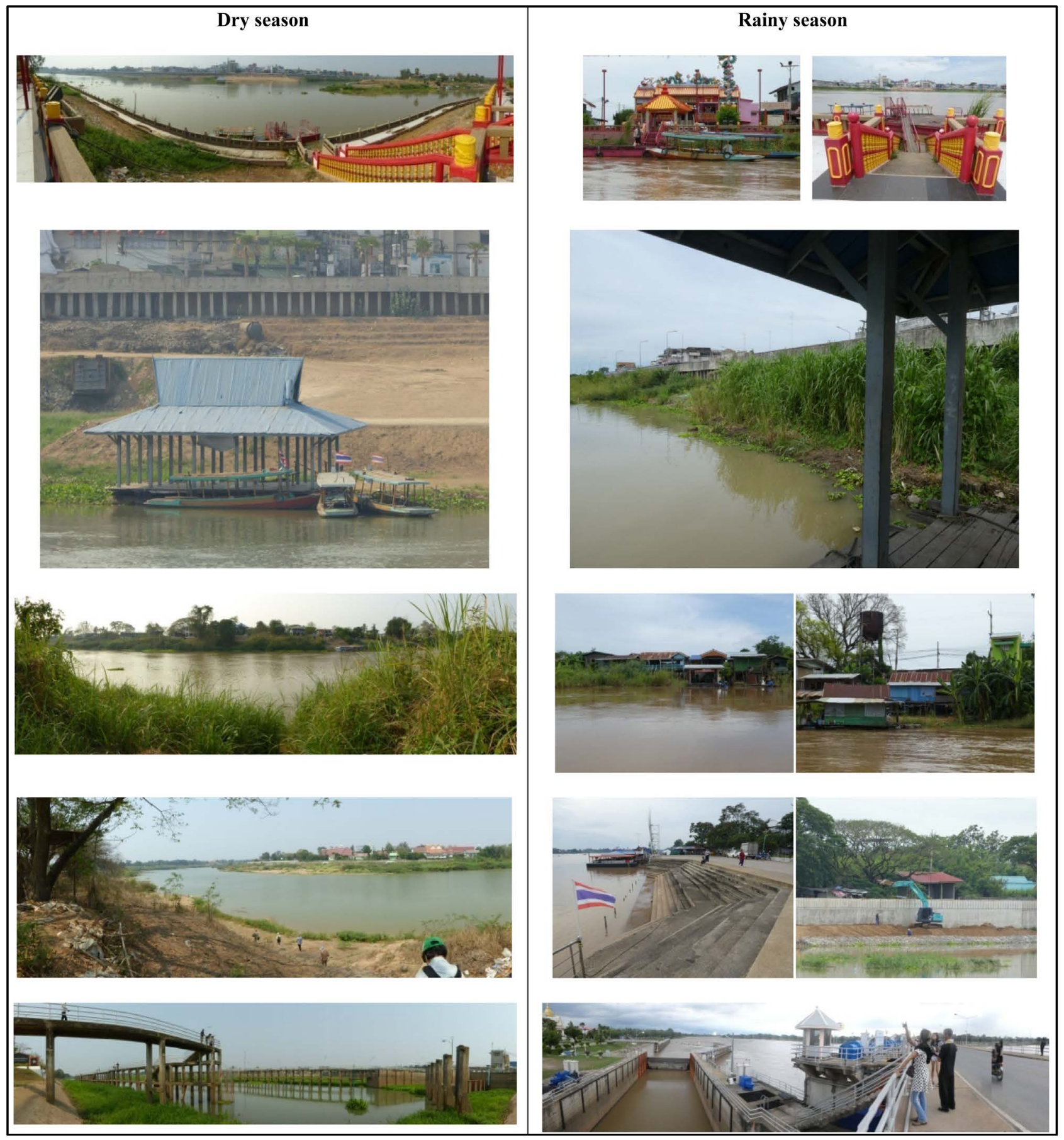

Figure 3. Survey location in the central plain upstream: steeper slope embankment in dry and rainy season.

the most profound was the transformation of human settlement systems. A century ago the vast majority of the world's population was rural, embedded in social and economic systems tied to agricultural production and living in dispersed, small-scale settlements [12]. The authors focused on the diverse aspects of the communities, and analyzed the existing conditions of these unique canal-front communities. There are three main key issues which we considered; abandoned structure, historical values, and community awareness in the future. With con- 
ventional technologies focused on the construction of structures, it has become difficult to keep urban spaces adaptable to environmental constraints and economic, social and cultural changes. Therefore, Sorensen \& Okata [12] (ibid) suggested to integrate the following technologies:

- concerned with environmental and risk management

- the conservation and regeneration of the local historical and cultural resources

- the communication, consensus building, plan making and space management to coordinate with various actors

It is important to search for a solution that involves the dilemma of reconciling competing local preferences while responding to trends in heritage conservation and urban waterfront redevelopment. Urban waterfront conservation involves a variety of cultural dimensions and needs that give rise to development opportunities. The need for an appreciation of the interdependence of geography and history is perhaps most fundamental to an understanding of the place. The juxtaposition of, on the one hand, increasing awareness of cultural heritage and an increasing willingness to promote cultural conservation with, on the other hand, very limited local economic resources inevitably results, without external assistance, in extremely slow progress or, in a worst-case scenario, in decline and disintegration [13].

1) the preservation, conservation and renewal of the historical fragments of urban space;

2) the refurbishment of buildings of character and interest;

3) the small-scale redesign of open spaces;

4) the introduction of appropriately signed historical and archaeological promenades;

5) the integration of such features into a continuous system of pedestrian public open spaces.

\subsection{The Transformation and Resilience of the Communities}

There is an embankment construction project in the survey, when it was almost completed, some parts collapsed and that caused damage to the surrounding communities. The effects are divided into physical and affective attitudes. Public participation does not happen as it should be and question to the participation procedure, whether or not it included the local wisdom-based community participation, especially those related to the lunar tides which caused erosion by mechanical action due to seepage from dynamic nature of spring tides (Figure 4).

From the many post flood constructions, there are different scopes of rehabilitation, which can be summarized as follows [14]; 1) Restoration, 2) Renaturalisation or naturalization, 3) Rehabilitation, and 4) Enhancement. In addition, Cengiz (2013) also mentioned five Planning Principles-PPs [14] (ibid) and eight general principles set the stage for design success or in-short; Design Principles-DPs [15]. 
PP 1: Demonstrate characteristics of the city's unique relationship with the river in the riverfront design

PP 2: Know the river ecosystem and plan for a scale larger than the riverfront

PP 3: Because rivers are dynamic, minimize new floodplain development

PP 4: Provide public access, connections, and recreational opportunities

PP 5: Celebrate the river's environmental and cultural history through public education programs, riverfront signage and events

DP 1. Protect natural river features and functions

DP 2. Buffer sensitive natural areas

DP 3. Restore riparian and in-stream habitats

DP 4. Use nonstructural alternatives to manage water resources

DP 5. Reduce hardscapes

DP 6. Manage stormwater on-site and use nonstructural approaches

DP 7. Balance recreational and public access goals with river protection

DP 8. Incorporate information about a river's natural resources and cultural history into the design of riverfront features, public art, and interpretive signs

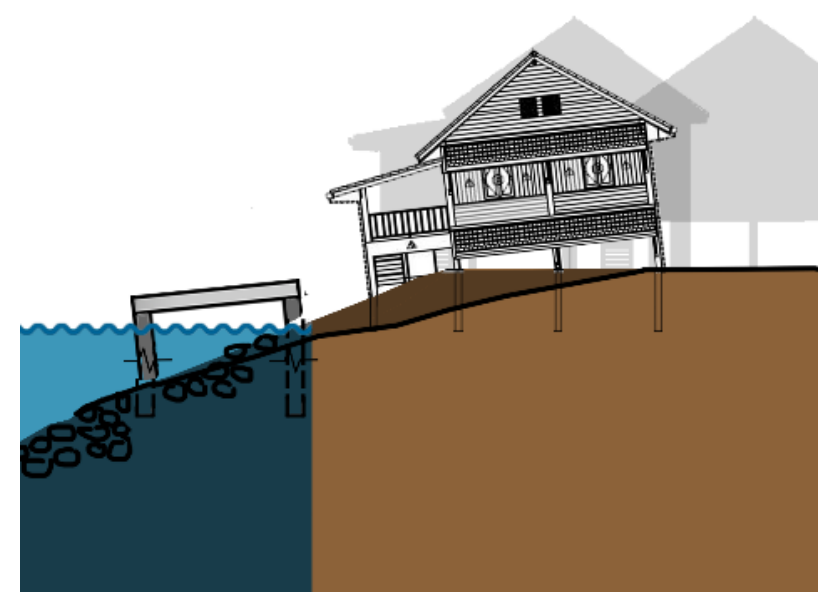

Figure 4. Sketch of flood protection structure and its impact to waterfront community. Source: P. Phukumchai [22] \& A. Aruninta, 2018.

Those principles for an ecologically sound riverfront design: PP 5: Celebrate the river's environmental and cultural history through public education programs, riverfront signage and events. Riverfronts have a rich human and natural history. Informative and path-finding systems can define the river, its environment and how river and city history are connected. Certain activities like educational and cultural programs, performances and public art events can be organized to attract people to the riverfront. And DP 8: Incorporate information about a river's natural resources and cultural history into the design of riverfront features, public art, and interpretive signs: The history and function of rivers may not be known well by the public. A conscious and well-informed society will understand the river [14] [15] [16].

During the past decades, the decline of the agricultural economy, and the hi- 
therto relatively unsuccessful search for economic diversification, has encouraged the heritage industry and tourism promotion [13] (ibid). This tended to shift the life style of the riverfront communities. The development of riverfront landscape has relied on the modern way of living together with new water management schemes.

\subsection{Implication of Spirit of Living with Water in Thai Cultural Landscape}

The transboundary nature in the multi-disciplinary research and holistic approaches will offer us the most efficient instruments to sustain urban development policies. Thai people in the former time were accustomed to river flood and developed a way of living in this vast floodplain and had wisely used a long inundation during flood time in the Delta as the natural weapons against her country's enemy. Until recently, from 1970, when a modern water resources development scheme was constructed and significantly improve the living condition, enhance economic activities through better regulation of water and reduction of flood in the delta [17].

Molle, Foran and Floch [18] also defined "waterscapes" as an expression of the interaction between humans and their environment and encompass all of the social, economic and political processes through which water in nature is conceived of and manipulated by societies. In other words, waterscapes are landscapes viewed through the lens of their water resources, taken as a defining element of both ecosystems and human life.

Rice culture is known as the most important cultural landscape of the Chao Phraya River Delta. One of characteristics is floating rice farming. It can be summarized as low input and low yield but sustainable farming. Modern technology need to be mixed well to search for sustainable agricultural system including water management and marketing. Not only preference in economics but also future prosperity in the delta area has to be discussed among all necessary stakeholders [19]. In the old day, rice and paddy field were our economic indicators. The "sakdina system" of the Ayutthaya period is known as a hierarchical system with ranking expressed in land units granted by the crown. But the land grants seemed not to be systematically attached to these positions [20]. Recently, the development of new economic indicators is not agriculture land but the land prices are manipulated by industrial estates development. It has radically altered the traditional vision of the province as the cradle of rice and water (ou khao ou nam) [21].

\section{Conclusion}

The results from the research raise a question whether we should live our life to the economic development or turn back to our origin. The cultural landscape and the waterfront landscape change and shift the Thai way of life that may severely impact country sustainability and food security to our future generations. 
Best practices in design and planning the riverfronts should be emphasized on the issues of the river's environmental and cultural history through educational and cultural programs. The incorporation of information about a river's natural resources and cultural history should also be conceptualized into the design of riverfront features. Finally, adopting local wisdom-based community participation should be encouraged to mitigate the future impacts from the riverfront construction.

\section{Acknowledgements}

We would like to show our gratitude to Hokkaido University and Chulalongkorn University collaboration program for giving the authors a chance to work continuously for many years on the field surveys of the Chao Phraya River in addition to our own motion in doing research on the living with water, especially after the worst flood during the years 2012-2013. In addition, we would like to thank DG College of Architecture, Chelembra, the University of Calicut for inviting us to present this research paper in the 4th International Research Seminar in Landscape Architecture and Planning in Culticut, Kerala, India on 15-16 Jan 2019.

\section{Conflicts of Interest}

The authors declare no conflicts of interest regarding the publication of this paper.

\section{References}

[1] Benke, A., Chaubey, I., Ward, G. and Dunn, E. (2000) Flood Pulse Dynamics of an Unregulated River Floodplain in the Southeastern U.S. Coastal Plain. Ecology, 81, 2730-2741.

[2] Vongvisessomjai, S. (2006) Chao Phraya Delta: Paddy Field Irrigation Area in Tidal Deposit. Seminar on Irrigation Technologies for Sustainable Agricultural Development, Thailand, 7 August 2006, 1-54.

[3] Jarupongsakul, T. and Kaida, Y. (2000) The Imagescape of the Chao Phraya Delta into the Year 2020. Proceeding. International Conference on the Chao Phraya Delta: Historical Development, Dynamics and Challenges of Thailand s Rice Bowl, Bangkok, 12-14 December 2000, 39 p.

[4] Molle, F. and Srijantr, T. (1999) Agrarian Change and the Land System in the Chao Phraya Delta. Research Report No. 6, Kasetsart University DORAS Project, Bangkok.

[5] Takaya, Y. and Hawkes, P. (1987) Agricultural Development of a Tropical Delta-Study of the Chao Phraya Delta. University of Hawaii Press, Honolulu, 19.

[6] Manarangsan, S. (1989) Economic Development of Thailand, 1850-1950: Response to the Challenge of the World Economy. Institute of Asian Studies, Chulalongkorn University, Bangkok, 55.

[7] Cheyroux, B. (2000) Fruits and Vegetables in Thailand's Rice Bowl: The Agricultural Development of Poldered Raised Bed Systems in Damnoen Saduak Area. Proceeding. International Conference on the Chao Phraya Delta: Historical Development, Dynamics and Challenges of Thailand's Rice Bowl, Bangkok, 12-14 December 2000, $17 \mathrm{p}$. 
[8] Molle, F., Chompadist, C., Srijantr, T. and Keawkulaya, J. (2001) Dry-Season Water Allocation and Management in the Chao Phraya Delta. Kasetsart University, Bangkok, 278 p.

[9] Weesakul, S. and Thammasittirong, S. (2000) Operational Flood Forecasting for Chao Phraya River Delta. Proceeding. International Conference on the Chao Phraya Delta: Historical Development, Dynamics and Challenges of Thailand's Rice Bowl, Bangkok, 12-14 December 2000, 14 p.

[10] Hinsharanan, N. (2000) Chao Phraya River and Canal Network Nostalgia of Aquatic Heritage. Proceeding. International Conference on the Chao Phraya Delta: Historical Development, Dynamics and Challenges of Thailand's Rice Bowl, Bangkok, 12-14 December 2000, 1 p.

[11] The Izaak Walton League of America (2006) A Handbook for Stream Enhancement \& Stewardship. McDonald \& Woodward Publishing, Granville.

[12] Sorensen, A. and Okata, J. (2011) Megacities: Urban Form, and Sustainability. Megacities. In: Library for Sustainable Urban Regeneration, Vol. 10, Springer, Tokyo. https://doi.org/10.1007/978-4-431-99267-7

[13] Hoyle, B. (2002) Urban Waterfront Revitalization in Developing Countries: The Example of Zanzibar's Stone Town. The Geographical Journal, 168, 141-162.

[14] Cengiz, B. (2013) Urban River Landscapes. In: Murat, O., Ed., Advances in Landscape Architecture, InTech, London, 551-586. https://doi.org/10.5772/56156

[15] Otto,B., Mccormick, K. and Leccese, M. (2004) Ecological Riverfront Design: Restoring Rivers, Connecting Communities. American Planning Association, Chicago, Planning Advisory Service Report No. 518-519.

[16] Schanze, J., Olfert, A., Tourbier, J.T., Gersdorf, I. and Schwager, T. (2004) Existing Urban River Rehabilitation Schemes. (Work Package 2) Final Report.

[17] Hungspreug, S., Khao-uppatum, W. and Thanopanuwat, S. (2000) Flood Management in Chao Phraya River Basin. Proceeding. International Conference on the Chao Phraya Delta: Historical Development, Dynamics and Challenges of Thailand s Rice Bowl, Bangkok, 12-14 December 2000, 20 p.

[18] Molle, F., Foran, T. and Floch, P. (2009) Introduction: Changing Waterscapes in the Mekong Region-Historical Background and Context. In: Molle, F., Foran, T. and Käkönen, M., Eds., Contested Waterscapes in the Mekong Region: Hydropower, Livelihoods and Governance, Earthscan, UK, 1-19.

[19] Sathianpantarit, P., Mujalinvimuti, A., Klinkhachorn, P., Punyachom, A., Jirasirisopon, S. and Yuyama, Y. (2000) Water Management in the Upper East Bank of the Chao Phraya Delta. Proceeding. International Conference on the Chao Phraya Delta: Historical Development, Dynamics and Challenges of Thailands Rice Bowl, Bangkok, 12-14 December 2000, 25 p.

[20] Phongpaichit, P. and Baker, C. (1997) Thailand: Politics and Economy. Oxford University Press, New York.

[21] Molle, F. and Srijantr, T. (2010) Thailand's Rice Bowl Perspectives on Agricultural and Social Change in the Chao Phraya Delta. White Lotus Press, Bangkok, Thailand, 21.

[22] Phukumchai, P. (2019) Public Participtory Approach to Mitigate Adverse Effect of the Chaophraya River Embankment Construction Project to the Riverfront Communities: In Pak Kret Area Nonthaburi. Thesis in Landscape Architecture, Chulalongkorn University, Bangkok, Thailand. 